Article

\title{
Effects of Heat Treatment on the Tribological Properties of Sicp/Al-5Si-1Cu-0.5Mg Composite Processed by Electromagnetic Stirring Method
}

\author{
Ning $\mathrm{Li}^{1,2}$, Hong Yan ${ }^{1, *}$ and Zhi-Wei Wang ${ }^{1}$ \\ 1 School of Mechanical Electrical Engineering, Nanchang University, Nanchang 330031, China; \\ lining@nchu.edu.cn (N.L.); wangzhiw@landwind.com (Z.-W.W) \\ 2 School of Aviation Manufacturing Engineering, Nanchang Hangkong University, Nanchang 330069, China \\ * Correspondence: hyan@ncu.edu.cn; Tel.: +86-791-8396-9633; Fax: +86-791-8396-9622
}

Received: 29 January 2018; Accepted: 1 March 2018; Published: 4 March 2018

\begin{abstract}
This paper investigated the influence of heat treatment (T6) on the dry sliding wear behavior of $\mathrm{SiCp} / \mathrm{Al}-5 \mathrm{Si}-1 \mathrm{Cu}-0.5 \mathrm{Mg}$ composite that was fabricated by electromagnetic stirring method. The wear rates and friction coefficients were measured using a pin-on-disc tribometer under loads of $15-90 \mathrm{~N}$ at dry sliding speeds of $100 \mathrm{r} / \mathrm{min}, 200 \mathrm{r} / \mathrm{min}$, and $300 \mathrm{r} / \mathrm{min}$, over a sliding time of $15 \mathrm{~min}$. The worn surfaces and debris were examined using a scanning electron microscope and was analyzed with an energy dispersive spectrometer. The experimental results revealed that $\mathrm{SiCp} / \mathrm{Al}-5 \mathrm{Si}-1 \mathrm{Cu}-0.5 \mathrm{Mg}$ alloy treated with $\mathrm{T} 6$ exhibited lower wear rate and friction coefficient than the other investigated alloys. As the applied load increased, the wear rate and friction coefficient increased. While, the wear rate and friction coefficient decreased with the sliding speed increasing. The morphology of the eutectic silicon was spheroidal after the T6 heat treatment. SiCp particles and $\mathrm{Al}_{2} \mathrm{Cu}$ phase can be considered as the main raisons for improving the wear behavior. Abrasion and oxidation were the wear mechanisms at low load levels. However, the wear mechanisms at high load levels were plastic deformation and delamination.
\end{abstract}

Keywords: heat treatment; $\mathrm{SiCp} / \mathrm{Al}-5 \mathrm{Si}-1 \mathrm{Cu}-0.5 \mathrm{Mg}$ composite; wear resistance; wear mechanisms

\section{Introduction}

In recent years, Al-Si alloys have been widely used in the manufacture of vehicles, due to their excellent physical properties, including low desity, high strength-to-weight ratio, good fluidity, low coefficient of thermal expansion and good machinability [1]. However, under the conditions of the traditional casting process, Al-Si alloys usually contain massive coarse, long-needle or lamellar shape eutectic Si phases. Those defects often lead to poor mechanical properties and wear resistance.

The addition of rare earth (RE) [2], $\mathrm{Sr}[3], \mathrm{Al}_{2} \mathrm{O}_{3}$ [4], or SiC [5,6], and heat treatment [7], are effective ways to change the morphology and distribution of the eutectic silicon phase in the $\mathrm{Al}$ matrix to improve the mechanical properties of the alloy. Xiaofan Du [5] studied the effect of situ synthesizing SiC particles on the Al-Si alloy. An in situ 2\% SiCp reinforced Al-Si alloy was designed. The hardness and wear resistance were improved. Besides, it was regarded that the in situ SiC particulates act on the process of heat treatment, which affected the mechanical properties as a result. But, the samples were prepared by traditional method and the wear mechanisms were not analysed. Rajeev et al. [6] studied the wear behavior of the Al-Si-SiCp composites by using a reciprocating friction wear test. This study showed that nomal load, reciprocating velocity, sliding distance, and silicon content all had a significant effect on the wear property of the samples. Among these factors, it was found that the increased Si content altered the composites' wear resistance. On the other hand, Gupta et al. [8] studied the microstructures of the Al-Si alloy and found that they were altered by T6 
heat treatment. T6 heat treatments increased the hardness, strength, elongation, and wear resistance of the alloy. Singh J et al. [9] reported the influence of wear test parameters on the wear performance of Al-composites of mechanical parameteres, such as: applied load, sliding velocity, sliding distance, temperature, and counterface hardness. The results revealed that these parameters can influence the wear and tribology behaviors of Al-composites in dry sliding wear tests.

Recently, the process of non-contacting method using an electromagnetic field is being conducted. When compared to traditional stirring casting, this method has the advantages of nonpollution, easy process control, and continuous production [10]. It has been a main method for producing the semi-solid slurry or billets. Therefore, electromagnetic stirring (EMS) is one of the most promising methods for processing cast products. EMS with optimal parameters has a remarkable ability to improve the macrosopic quality of billet [11]. Stirring power is a key process factor and has a direct and positive influence on microstructural evolution [12-14]. The suitable slight electromagnetic stirring that is applied to the melt during the low superheat pouring can increase the number of crystal nuclei in the melt to reduce the grain size, and can make the primary phase morphology to become more round. Dwivedi [15] believed that this process resulted in the distribution of SiC particles evenly with a low porosity. Dwivedi found that SiCp were evenly distributed in the matrix due to the melt flow that is induced by the rotating magnetic field of electromagnetic stirring. This indicates the effectiveness of the technique electromagnetic stir casting process that is utilized for the production. In a word, the EMS method can improve the mechanical properties and microstructural composition of the alloy, and may improve the wear resistance of the alloy.

Few literatures can be found to reveal the effect of $\mathrm{T} 6$ heat treatment on the wear properties of Al-Si alloys that are reinforced with $\mathrm{SiCp}$ processed by electromagnetic stirring method. $\mathrm{T} 6$ heat treatment refers to a solution treatment at $520-550{ }^{\circ} \mathrm{C}$ for several hours, followed by quenching and artificial ageing [16]. In the present work, $\mathrm{Al}-5 \mathrm{Si}-1 \mathrm{Cu}-0.5 \mathrm{Mg}$ alloy, which is hypoeutectic $\mathrm{Al}-\mathrm{Si}$ alloy, was adopted as the matrix. An electromagnetic stirring technique was used to prepare the $\mathrm{SiCp} / \mathrm{Al}-5 \mathrm{Si}-1 \mathrm{Cu}-0.5 \mathrm{Mg}$ composite. After T6 heat treatment, the microstucture, tensile strength, hardness and elongation of the composite were tested. A pin-on-disc test was also carried on to investigate the heat treatment on the wear properties of $\mathrm{SiCp} / \mathrm{Al}-5 \mathrm{Si}-1 \mathrm{Cu}-0.5 \mathrm{Mg}$ composite processed by electromagnetic stirring method. The wear mechanisms of the tests were analyzed by scanning electron microscope (SEM) and energy dispersive spectroscopy (EDS).

\section{Experimental}

\subsection{Materials Preparation}

The addition of SiCp reinforcement to a metal matrix provides considerably better wear and thermal properties [17]. Therefore, SiCp particles with an average size of about 2 um were chosen as the reinforcement particles. The SEM image of the received SiCp particles is shown in Figure 1. The SiCp was pretreated by high temperature oxidation (oxidation for $4 \mathrm{~h}$ under $1000{ }^{\circ} \mathrm{C}$ ). Because the SiCp without pretreatment is prone to forming a harmful, brittle $\mathrm{Al}_{4} \mathrm{C}_{3}$ phase when it directly comes into a molten $\mathrm{Al}$ matrix. The high temperature oxidation also improved the wettability of $\mathrm{SiCp}$ and the molten Al.

An electromagnetic stirrer (EMS-SM05) was used for the preparation of the materials. Figure 2 shows a schematic diagram of the electromagnetic stirring set-up. The electromagnetic frequency was $35 \mathrm{~Hz}$ and the current was $57.5 \mathrm{~A}$. The stirring nominal power was $20,125 \mathrm{~W}$. 


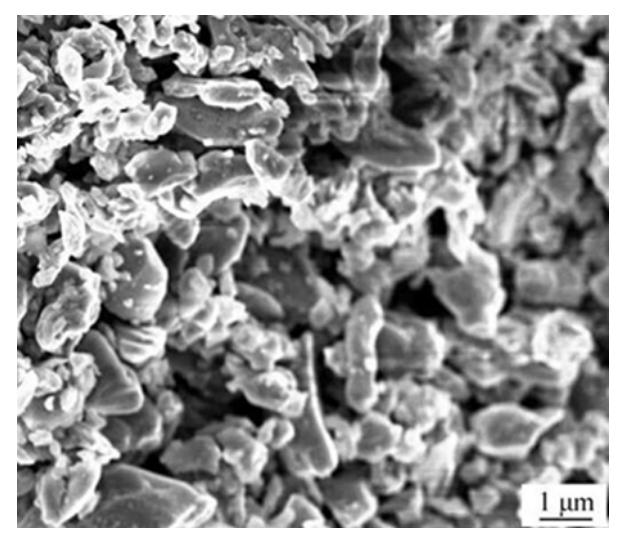

Figure 1. SEM (scanning electron microscope) image of the received SiC particles.

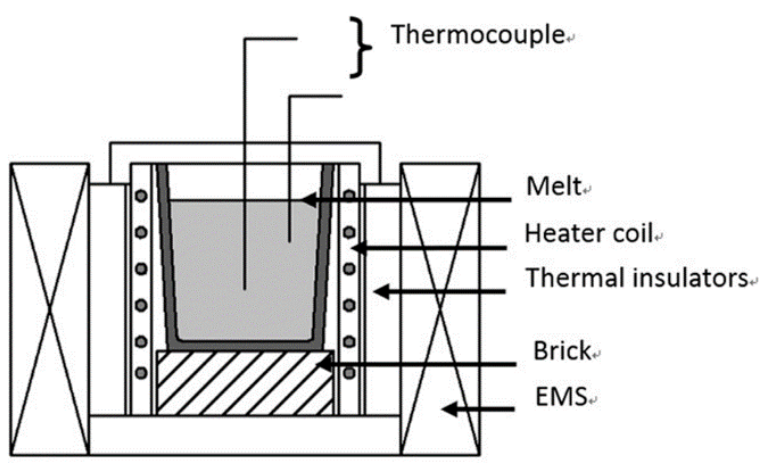

Figure 2. The diagram of electromagnetic stirrer. EMS: electromagnetic stirring.

Ingots of $\mathrm{Al}-5 \mathrm{Si}-1 \mathrm{Cu}-0.5 \mathrm{Mg}$ alloy were used as the matrix alloy in this research, and the compositions of this alloy were listed in Table 1 . The Al-5Si-1Cu-0.5Mg alloy ingot was melted at $750{ }^{\circ} \mathrm{C}$ and held for $10 \mathrm{~min}$ before the power of the electromagnetic stirrer set-up was turned off (as shown in Figure 2). When the temperature was decreased to $635^{\circ} \mathrm{C}$, the stirrer was started and the $\mathrm{SiCp}$ alloy was added. After that, the temperature of the furnace decreased at a constant cooling rate of $4{ }^{\circ} \mathrm{C} / \mathrm{min}$. When the temperature decreased to $585^{\circ} \mathrm{C}$, the stirrer was stopped. Then, the molten alloy was heated to $650{ }^{\circ} \mathrm{C}$ again and poured into a permanent mold. Subsequently, the fabricated $1.5 \mathrm{wt} \% \mathrm{SiCp} / \mathrm{Al}-5 \mathrm{Si}-1 \mathrm{Cu}-0.5 \mathrm{Mg}$ alloy was subjected to a solution treatment at $520 \pm 2{ }^{\circ} \mathrm{C}$ for $6 \mathrm{~h}$, and then quenched in room-temperature water. Those samples that had been solution-treated were aged at $175 \pm 2{ }^{\circ} \mathrm{C}$ for up to $6 \mathrm{~h}$ and then air-cooled to room temperature. As a result, three types of samples were generated for the wear tests: the Al-5Si-1Cu- $0.5 \mathrm{Mg}$ alloy, the $1.5 \mathrm{wt} \% \mathrm{SiCp} / \mathrm{Al}-5 \mathrm{Si}-1 \mathrm{Cu}-0.5 \mathrm{Mg}$ alloy, and the $1.5 \mathrm{wt} \% \mathrm{SiCp} / \mathrm{Al}-5 \mathrm{Si}-1 \mathrm{Cu}-0.5 \mathrm{Mg}$ alloy with $\mathrm{T} 6$.

Table 1. Chemical composition of the Al-5Si-1Cu-0.5Mg aluminum alloy used in the experiment (mass fraction, $\%)$.

\begin{tabular}{cccccc}
\hline $\mathbf{S i}$ & $\mathbf{C u}$ & $\mathbf{M g}$ & $\mathbf{T i}$ & $\mathbf{F e}$ & Al \\
\hline 5.13 & 1.27 & 0.55 & 0.16 & 0.13 & Bal. \\
\hline
\end{tabular}

\subsection{Wear Testing}

The dry sliding wear test was carried out using a MMD-1 (Jinan Yihua Tribology Testing Technology Co., Ltd., Jinan, China) pin-on-disc apparatus at room temperature. The wear rates and friction coefficients results were the average value of the three tests. Pin samples were machined 
into rods of $\Phi 4.5 \mathrm{~mm} \times 11 \mathrm{~mm}$. The disc material was ASTM1045 steel of 45HRC. Before each test, the pin and disc surfaces were ground with 600, 1200, 1500, and 2000-grit SiC abrasive paper successively, polished, and then cleaned with ethanol. The surface of the samples was polished to a roughness less than $0.1 \mu \mathrm{m}$ before wear testing. Three sliding speeds $100 \mathrm{r} / \mathrm{min}(0.188 \mathrm{~m} / \mathrm{s}), 200 \mathrm{r} / \mathrm{min}(0.377 \mathrm{~m} / \mathrm{s})$, $300 \mathrm{r} / \mathrm{min}(0.565 \mathrm{~m} / \mathrm{s}))$ and a sliding duration of $15 \mathrm{~min}$ were selected as metrics for the tests, while four different applied loads $(15,30,60$ and $90 \mathrm{~N})$ were used. The weight of the pins was measured using a FA2204B electronic balance with an accuracy of $\pm 0.1 \mathrm{mg}$. All volume loss values were calculated by weight loss and the measured densities. Wear rates were estimated by dividing the volumetric wear loss by the sliding distance. Friction coefficients were the average values of the kinetic friction coefficients over a steady period of wear (after sliding for $5 \mathrm{~min}$ ).

\subsection{Characterization}

A Nikon Eclipse MA200 (Nikon Metrology, Inc., Brighton, UK) optical microscope (OM) was used to observe and analyze the microstructure evolution of the samples. The samples that were used for the OM examination were mounted and then polished and etched in an aqueous solution composed of $0.5 \mathrm{vol} \%$ HF. The micro-hardness was measured using a HVS-1000A Vickers hardness instrument (Laizhou Huayin Testing Instrument Co., Ltd., Laizhou, China). The set load was $300 \mathrm{~g}$ and $10 \mathrm{~s}$ duration. To evaluate tensile properties, the test samples were machined into tensile test bars with a diameter of $6 \mathrm{~mm}$ and a gauge length of $30 \mathrm{~mm}$, according to the ASTM B557M specification, which was carried out at room temperature using a SUNC UM5105 electro-servo testing machine with a tensile speed of $1 \mathrm{~mm} / \mathrm{min}$. To ensure the repeatability and consistency of the measurements, five samples were tested for tension under the same test conditon. The microstructures of the samples were observed using scan electron microscopy (FEI Quanta200F (FEI Trading (Shanghai) Co., Ltd., Shanghai, China)). EDS analysis was performed by an NCA 250XMax 50 instrument (Oxford instrument, Oxford, UK). The transmission electron microscopy (TEM) sample was cut from the composite with T6, then ground to less than $80 \mu \mathrm{m}$, and cut into a $3 \mathrm{~mm}$ diameter disk. Thin foil for TEM observation were prepared by twin-jet polishing with an electrolyte solution consisting of $10 \% \mathrm{HNO} 3$ and $90 \%$ methanol below $-30{ }^{\circ} \mathrm{C}$. TEM observation was carried out by JEM-2100 (Japan Electronics Co., Ltd., Tokyo, Japan) microscope. The porosity of each composite was calculated by dividing the difference value between experimental and theoretical densities by theoretical densitie.

\section{Results and Discussion}

\subsection{Microstructure Evolution}

Figure 3a shows the microstucture of the Al-5Si-1Cu-0.5Mg alloy as cast-fabricated while using the electromagnetic stirring method. The base alloy microstructre consists of an $\alpha$-Al (white) matrix surrounded by the eutectic Si (grey) phase of the needle or lamellar shape and the Fe-rich phase ( $\gamma$ phase) (sepia) of the intensive bone shape. The coarse grains and their inhomogeneous distribution produce stress concentration during loading and deformation, thus reducing the mechnical properties of the cast alloy. Figure $3 \mathrm{~b}$ shows that the appropriate addition of SiCp $(1.5 \mathrm{wt} \%)$ can refine the primary $\alpha-\mathrm{Al}$ and the eutectic $\mathrm{Si}$ and improve their distribution. Under the environment of the semi-solid slurry, $\mathrm{SiCp}$ inhibits the diffusion of solute elements, such as $\mathrm{Si}, \mathrm{Fe}$, and other elements, thereby limiting the nucleation and growth of second phase [18]. On the other hand, SiCp provides a nucleation point for $\mathrm{Si}$ eutectic phase. Thus, the nucleation rate increases and the size of the phase reduces. Moreover, the aspect ratio of the eutectic Si phase can also be reduced due to the addition of a proper amount of SiCp [19]. The Fe-rich phase was also changed from an intensive bone shape into a dispersion type. Figure $3 \mathrm{c}$ illustrates the microstructure of $\mathrm{SiCp} / \mathrm{Al}-5 \mathrm{Si}-1 \mathrm{Cu}-0.5 \mathrm{Mg}$ composites with heat-treatment. Spheroidization of the eutectic Si occurred during the solution treatment. After aging, there were some light grey $\gamma$ phases precipitated. Table 2 shows the results of the mechanical tests of the samples. It could be seen that the addition of SiCp effectively improved the mechanical 
properties of the cast $\mathrm{Al}-5 \mathrm{Si}-1 \mathrm{Cu}-0.5 \mathrm{Mg}$. Meanwhile, as Table 2 indicating, the mechnical properties of the $\mathrm{SiCp} / \mathrm{Al}-5 \mathrm{Si}-1 \mathrm{Cu}-0.5 \mathrm{Mg}$ composites treated with $\mathrm{T} 6$ were the best of all the tested alloys. After T6 treatment, the hardness, ultimate strength, and elongation of the composite were $101.86 \mathrm{HV}, 273.64 \mathrm{MPa}$, and $6.12 \%$, respectively. When compared to the ones of the samples not treated with $\mathrm{T} 6$, these values were increased by $17 \%, 14.68 \%$, and $17.02 \%$, respectively.
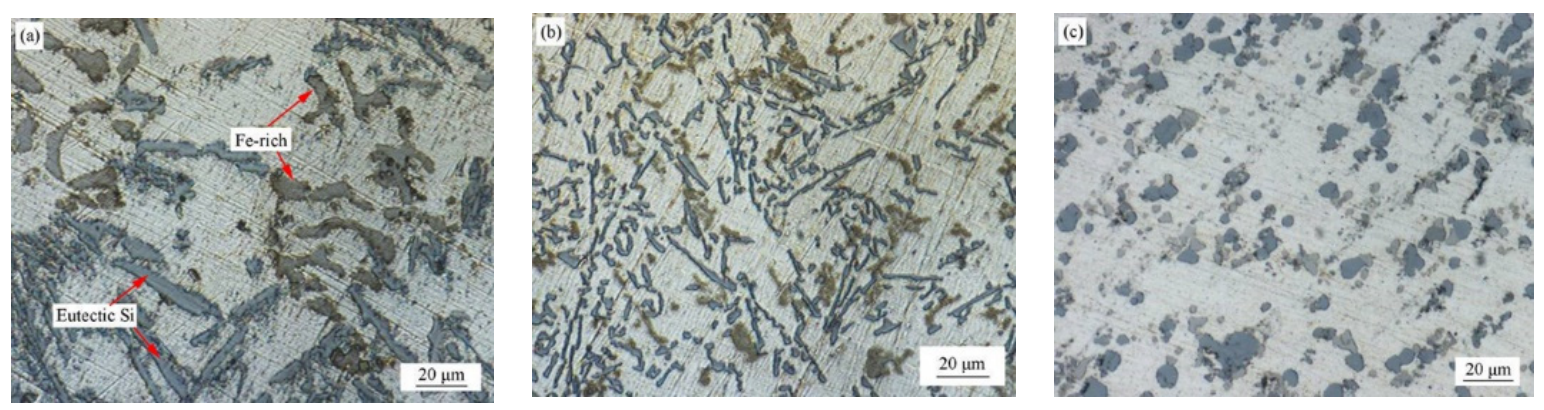

Figure 3. Microstructures of (a) Al-5Si-1Cu-0.5Mg alloy as cast, (b) SiCp/Al-5Si-1Cu-0.5Mg composites, and (c) T6 heat-treated $\mathrm{SiCp} / \mathrm{Al}-5 \mathrm{Si}-1 \mathrm{Cu}-0.5 \mathrm{Mg}$ composites.

Table 2. Some properties of the samples used in the wear tests.

\begin{tabular}{ccccc}
\hline Samples & $\rho /\left(\mathbf{g} \cdot \mathbf{c m}^{-3}\right)$ & Porosity/\% & Microhardness/HV & UTS/MPa \\
\hline Al-5Si-1Cu-0.5Mg & 2.695 & 0.55 & $80.17 \pm 3.50$ & $191.56 \pm 4.77$ \\
Al-5Si-1Cu-0.5Mg + SiCp & 2.699 & 0.61 & $87.06 \pm 4.39$ & $238.62 \pm 5.19$ \\
Al-5Si-1Cu-0.5Mg + SiCp + T6 & 2.698 & 0.65 & $101.86 \pm 1.59$ & $273.64 \pm 6.47$ \\
\hline
\end{tabular}

Figure $4 \mathrm{a}$ is the TEM morphology of $\mathrm{SiCp} / \mathrm{Al}-5 \mathrm{Si}-1 \mathrm{Cu}-0.5 \mathrm{Mg}$ composite after aging treatment. There are some needle-like precipitate phases (as the arrows shown in Figure 4a) with length of about $100 \mathrm{~nm}$ around the dislocation. Furthermore, EDS analysis (as shown in Figure $4 \mathrm{~b}$ ) of the precipitate phase revealed that aluminum and copper were the main compositions of the phase. According to Sjölander, E et al. [20], the precipitation phase could be $\mathrm{Al}_{2} \mathrm{Cu}$. The $\mathrm{Al}_{2} \mathrm{Cu}$ phase contribute to improve the hardness of the alloy. Moreover, SiCp pinning on the boundaries that could stabilize the sub-microstructure and speed up the aging reaction and increase the rate of work hardening [21].
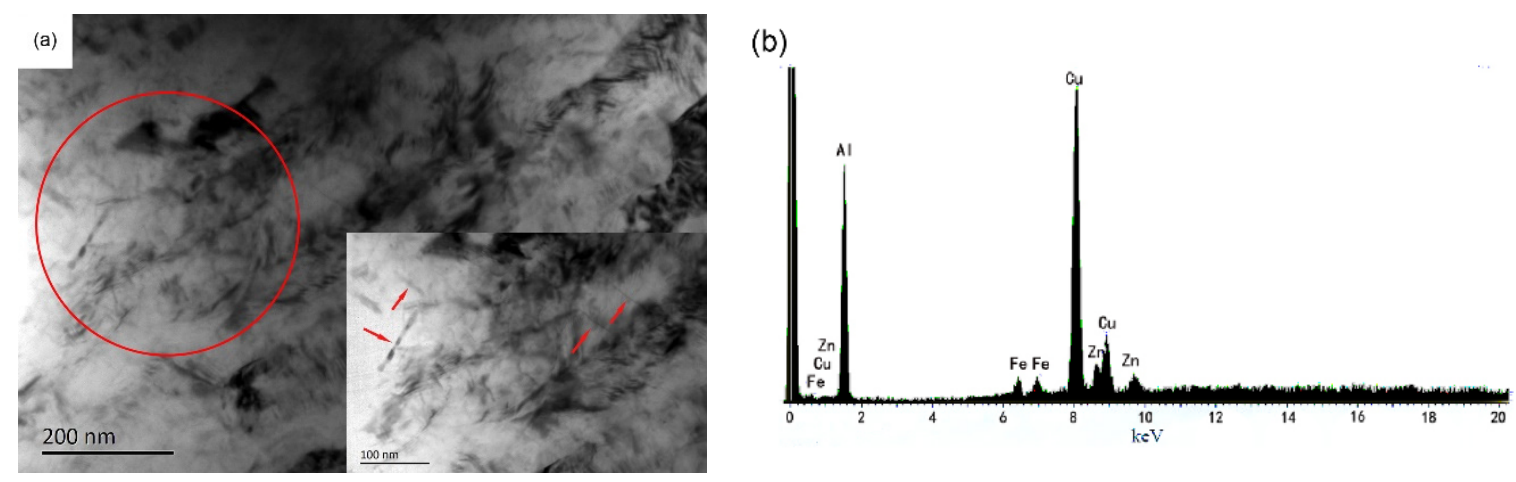

Figure 4. (a) TEM image and (b) EDS (energy dispersive spectroscopy) pattern of precipitates of $\mathrm{SiCp} / \mathrm{Al}-5 \mathrm{Si}-1 \mathrm{Cu}-0.5 \mathrm{Mg}$ composite after aging treatment.

\subsection{Wear Rates}

As shown in Figure 5, the wear rates for the three alloys are plotted against applied loads. The wear rates increased with load. The wear rate of the as-cast $\mathrm{Al}-5 \mathrm{Si}-1 \mathrm{Cu}-0.5 \mathrm{Mg}$ alloy was the largest among the ones of the tested alloys. At low load $(15 \mathrm{~N})$, the wear rate of the as-cast SiCp/Al-5Si-1Cu-0.5Mg 
showed almost the same as the one of the base alloy. However, when the load upped to $90 \mathrm{~N}$, the wear rate of the as-cast $\mathrm{SiCp} / \mathrm{Al}-5 \mathrm{Si}-1 \mathrm{Cu}-0.5 \mathrm{Mg}$ was only about half of the one of the matrix alloy. The results indicated that the addition of SiCp significantly improved the wear resistance of the Al-5Si-1Cu-0.5Mg alloy. Especially, treated by T6, the SiCp/Al-5Si-1Cu-0.5Mg alloy achieved further improvement of the wear resistance. The wear rates of the three alloys were inversely proportional to the micro-hardness of the alloys, which was consistent with the Achard's law [22]. It has been reported that the wear behavior of the alloys was affected by their microstructure and mechanical properties [23]. As mentioned before, the as-cast $\mathrm{Al}-5 \mathrm{Si}-1 \mathrm{Cu}-0.5 \mathrm{Mg}$ alloy microstructre consisted of an $\alpha$-Al matrix that was surrounded by the eutectic Si phase of the needle or lamellar shape, and the $\gamma$ phase of the intensive bone shape. This configuration produced stress concentration on the boundary of the $\alpha$-Al matrix, and the fracture occurred on the boundary interface, which caused the wear debris to fall out. With appropriate addition of SiCp, the shape of eutectic silicon was changed to a fine acicular or short stick or even a granular-like shape, and the $\gamma$ phase was also distributed uniformly. Therefore, the interface bonding strength of the secondary phase with the matrix was reinforced, the mechanical and wear resistance property was improved, and the wear rate was decreased. Treated by T6, the eutectic silicon was spheroidal in shape, and some light grey $\gamma$ phases were precipitated. As a result, the wear resistance property was improved.

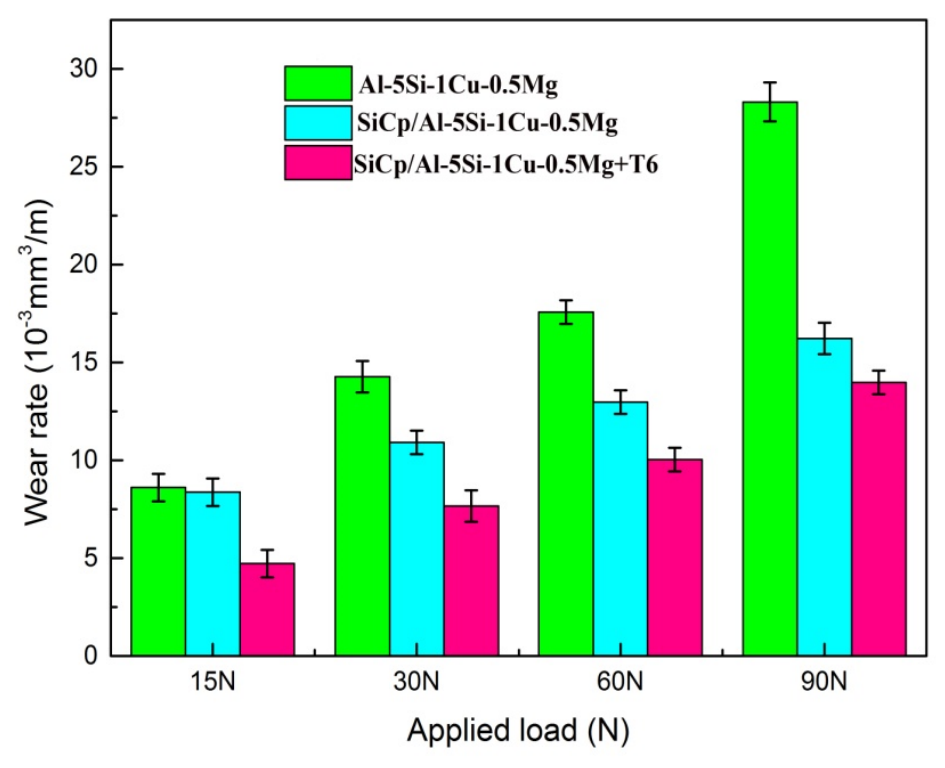

Figure 5. Wear rate values for samples under various applied loads.

Figure 6 illustrates that the wear rate decreases with the sliding speed increasing. As the sliding velocity increased, the worn surface became smooth and the amount of delaminating groove was decreased (Figure 7). At a higher sliding velocity, more frictional heat was generated. The heat generation could increase the plastic dedormation on the worn surface [23]. The deformation improved the hardening of the alloys. Therefore, the wear resistance property was improved. 


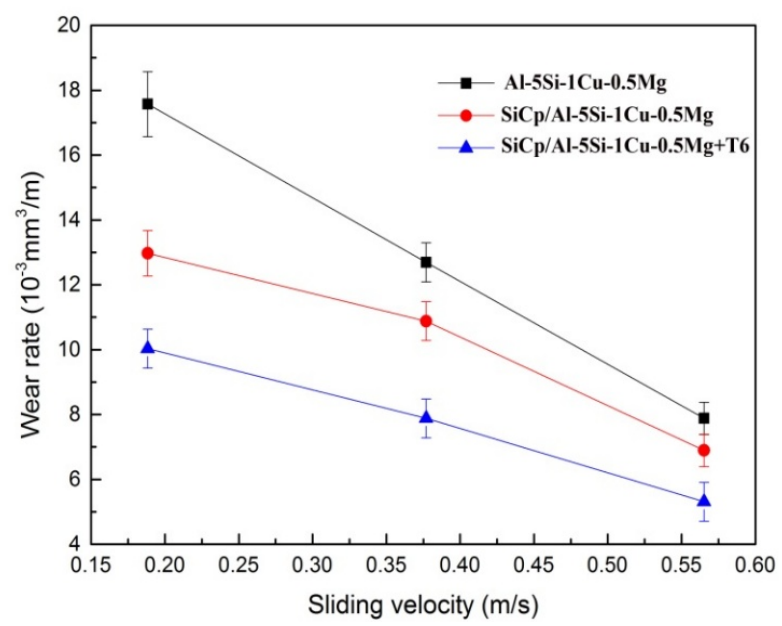

Figure 6. Wear rate values for samples at various Sliding velocity under a normal load of $60 \mathrm{~N}$.

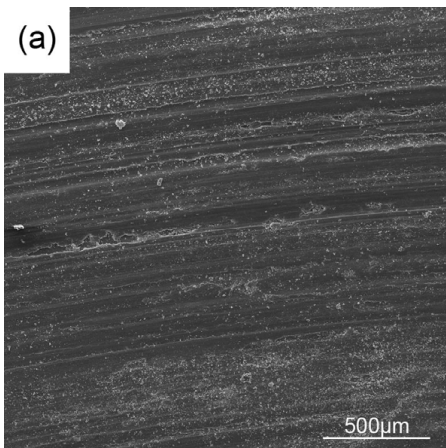

(c)
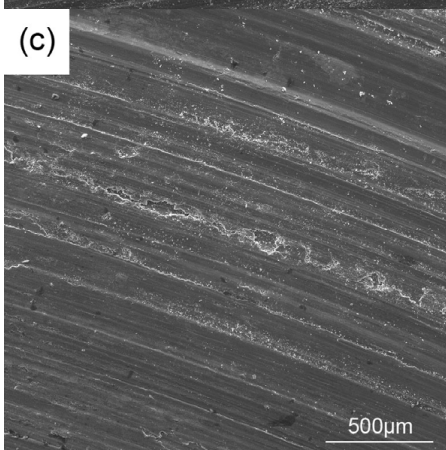

(b)

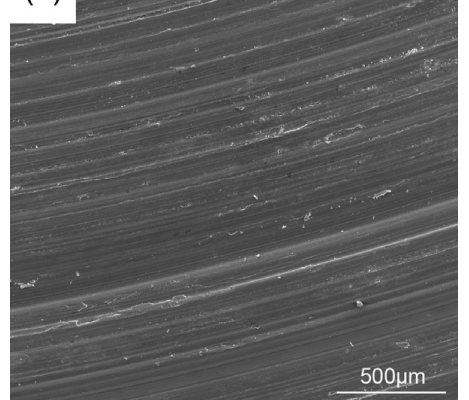

(d)

(e)

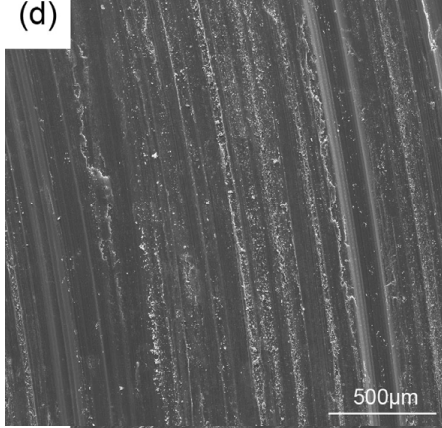

(f)
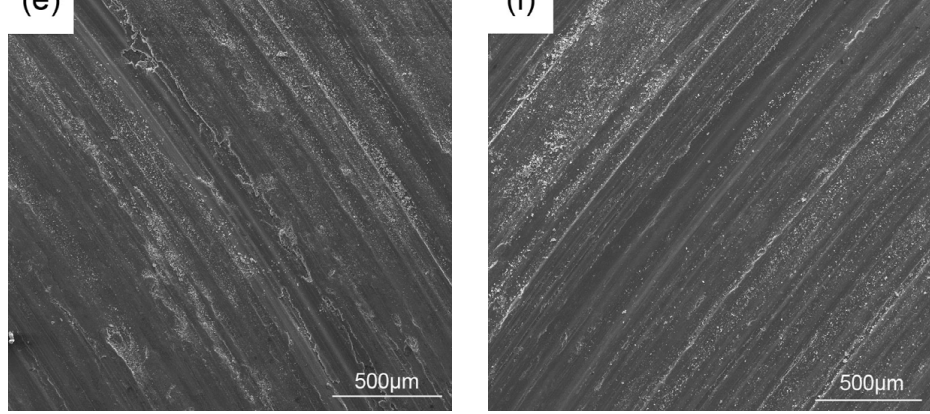

Figure 7. Worn surfaces of different alloys under a normal load of $60 \mathrm{~N}$ at different sliding speeds; (a) Al-5Si-1Cu-0.5Mg, $0.377 \mathrm{~m} / \mathrm{s}$, (b) Al-5Si-1Cu-0.5Mg, $0.565 \mathrm{~m} / \mathrm{s}$, (c) SiCp/Al-5Si-1Cu-0.5Mg, $0.377 \mathrm{~m} / \mathrm{s}$, (d) SiCp/Al-5Si-1Cu-0.5Mg, $0.565 \mathrm{~m} / \mathrm{s}$, (e) SiCp/Al-5Si-1Cu-0.5Mg with T6, 0.377 m/s, (f) $\mathrm{SiCp} / \mathrm{Al}-5 \mathrm{Si}-1 \mathrm{Cu}-0.5 \mathrm{Mg}$ with $\mathrm{T} 6,0.565 \mathrm{~m} / \mathrm{s}$. 
It has been recognized that under the condition of sliding with loading, strain hardening will be developed. The higher the sliding speed, the more pronounced the hardening of the alloy. SiCp particles and $\mathrm{Al}_{2} \mathrm{Cu}$ phase could act as effective barriers to dislocation motion during subsurface deformation, which increased the rate of work-hardening. It can be considered as the main mechanism of the wear behavior improvement. So, when added with $\mathrm{SiCp}, \mathrm{Al}-5 \mathrm{Si}-1 \mathrm{Cu}-0.5 \mathrm{Mg}$ alloy achieved a lower wear rate when compared with the one of the base alloy, and after T6 treatment, the wear rate value decreased further.

\subsection{Friction Coefficient}

The relationships between the frictional coefficients and applied loads are shown in Figure 8. The friction coefficient of the alloy treated with $\mathrm{T} 6$ was minimal under the same test conditions. This value decreased to its minimum $(0.3255)$ at the lowest load $(15 \mathrm{~N})$. The collected friction coefficient values of the tested alloys under different applied loads are listed in Table 3.

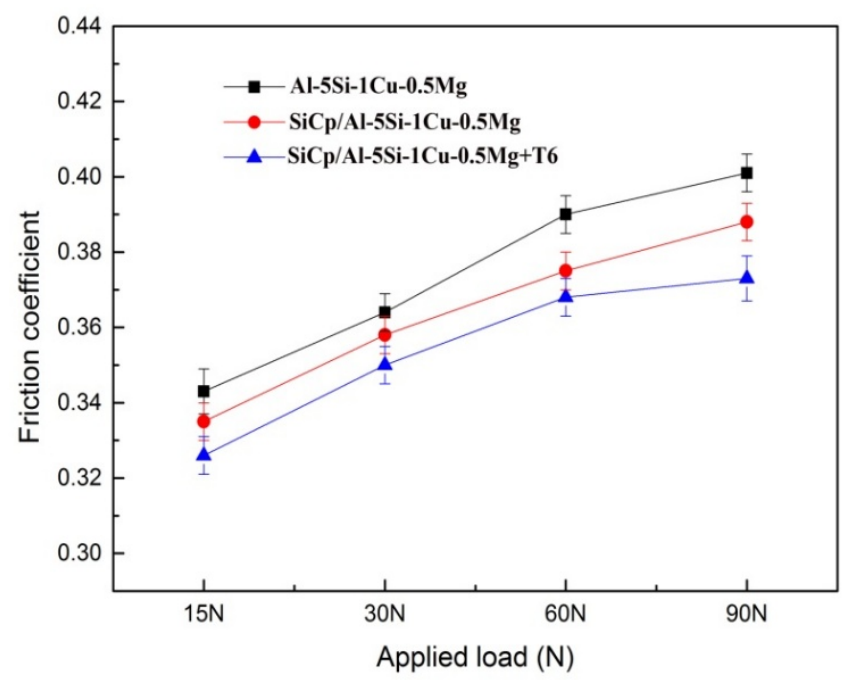

Figure 8. Coefficient of friction (COF) values for samples under various applied loads.

Table 3. Detailed Coefficient of friction (COF) values for samples at various applied loads.

\begin{tabular}{ccccc}
\hline Samples & $\mathbf{1 5} \mathbf{~ N}$ & $\mathbf{3 0 ~ N}$ & $\mathbf{6 0 ~ N}$ & $\mathbf{9 0 ~ N}$ \\
\hline Al-5Si-1Cu-0.5Mg & $0.343 \pm 0.003$ & $0.364 \pm 0.0025$ & $0.390 \pm 0.0025$ & $0.401 \pm 0.0025$ \\
Al-5Si-1Cu-0.5Mg + SiCp & $0.335 \pm 0.0025$ & $0.358 \pm 0.0025$ & $0.375 \pm 0.0025$ & $0.388 \pm 0.0025$ \\
Al-5Si-1Cu-0.5Mg + SiCp + T6 & $0.326 \pm 0.0025$ & $0.350 \pm 0.0025$ & $0.368 \pm 0.0025$ & $0.373 \pm 0.003$ \\
\hline
\end{tabular}

Bowden and Tabor's model for friction [24] regards friction as the resistance of asperities on one surface riding over the asperities of the matching surface. Under the same applied load, the friction coefficient and wear volume of the as-cast $\mathrm{Al}-5 \mathrm{Si}-1 \mathrm{Cu}-0.5 \mathrm{Mg}$ were all at maximum levels. The result showed that the wear debris fell out significantly between the asperities of the matching surface. This debris prevented the contact surfaces from sliding smoothly, and it significantly increased the friction force. The wear volume of the alloy with T6 treatment was minimal, few wear debris fell out, and the friction coefficient was low. In general, there is a proportional relationship among the friction coefficient and the microstructure or mechanical properties of the material $[23,25]$.

The friction coefficient values increased with the applied load. When the two surfaces interacted, contact does not take place over the entire surface area. The real contact area consists of very small contact points at asperity tips, which are called micro-contacts [26]. When load was applied on the sample, the micro-contacts needed to have enough plastic deformation to bear the applied normal load. The higher the load, the greater the extent of the plastic deformation, which led to larger tribo-surface 
removal. Consequently, the contact area between the friction pairs increased as the load increasing, as well as friction. From the view of Bowden and Tabor's model for friction, at high loads, wear debris increased and became lodged between the asperities that resisted the motion at the interface. As a result, the friction force and friction coefficient increased.

Figure 9a illustrates that the friction coefficient values decreasing with the sliding speed increasing. As Figure $7 \mathrm{~b}, \mathrm{~d}, \mathrm{f}$ shows, smooth worn surface were observed on the samples without oxide layer. The smooth worn surface could be ascribed to the softening of the alloy at higher surface temperature during sliding at a high speed. The smooth worn surface led to a low friction coefficient value at a high sliding speed. Meanwhile, the fluctuation amplitude of the friction coefficient was reduced, as shown in Figure 9b-d.
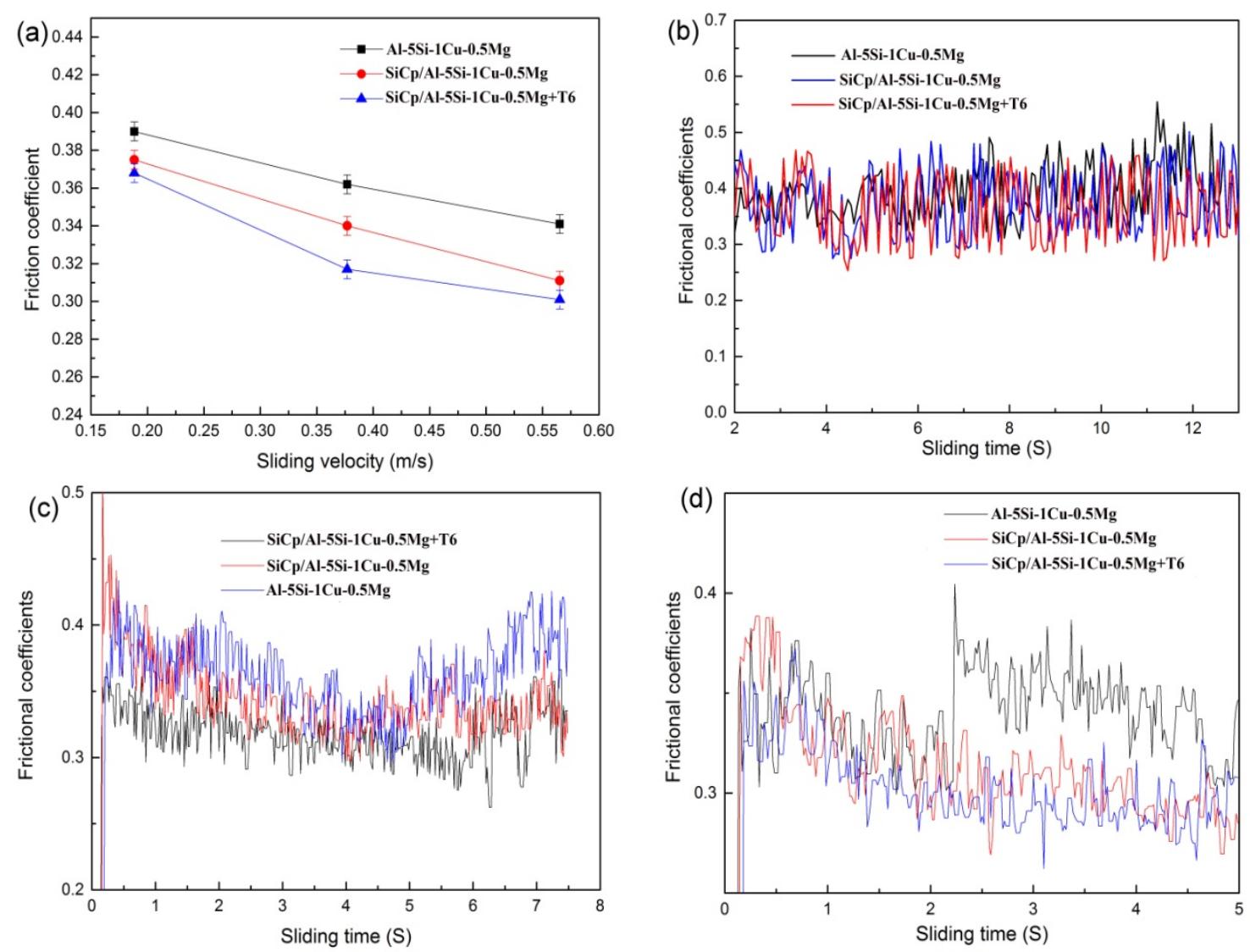

Figure 9. Friction coefficient for samples at various Sliding velocity under a normal load of $60 \mathrm{~N}$; (a) the average friction coefficient, (b) the friction coefficient in time, $0.188 \mathrm{~m} / \mathrm{s}$, (c) the friction coefficient in time, $0.377 \mathrm{~m} / \mathrm{s}$, (d) the friction coefficient in time, $0.565 \mathrm{~m} / \mathrm{s}$.

\subsection{Wear Mechanisms}

In this study, SEM morphologies of $90 \mathrm{~N}$ load worn surfaces were captured, as shown in Figure 10. Figure 10b,d,f show the enlarged SEM micrograph of the circle area of the dotted line referred in Figure 10a,c,e, respectively. When combined with the energy spectrum analysis results (shown in Figure 11), the morphologies exhibited that there were five different wear operating mechanisms: abrasion, oxidation, delamination, plastic deformation, and adhesion.

Due to the easily oxidized nature of aluminum, frictional heating during sliding under high load that was caused the oxide film on the surface of the pin sample generated. Studies by Lashgari et al. [27] and Dwivedi et al. [28] showed that the existence of the oxide film improved the wear behavior and reduced the friction coefficient because of the lubrication effect. At the same time, the oxide film 
prevented metal-to-metal contact, resulting in a low wear volume. EDS analysis of areas A and B, marked in Figure 10c,d, were revealed in Figure 11a,b. By contrast, more Fe was clearly present in the A area. The white powder (Figure 10c,d) represented the Fe-rich wear debris, and also consisted of some other elements, such as: $\mathrm{O}, \mathrm{Al}, \mathrm{Si}$, and $\mathrm{Cu}$. The wear debris was closely related to abrasive wear.
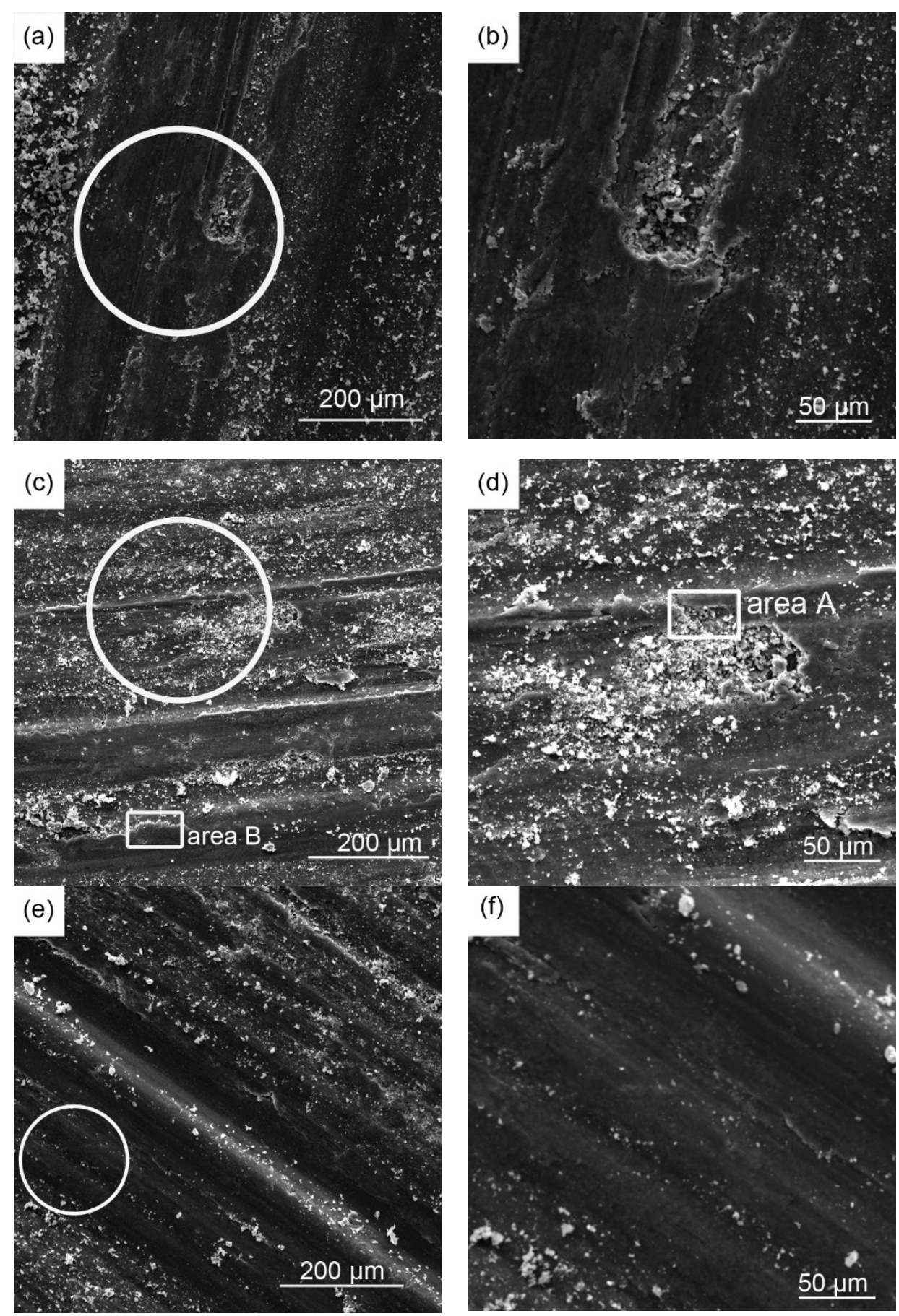

Figure 10. SEM images of samples under a normal load of $90 \mathrm{~N}$ at sliding speed of $0.188 \mathrm{~m} / \mathrm{s}$. (a,b) Al-5Si-1Cu-0.5Mg alloy, (c,d) SiCp/Al-5Si-1Cu-0.5Mg composites before T6 treatment and $(\mathbf{e}, \mathbf{f})$ after T6 treatment. 

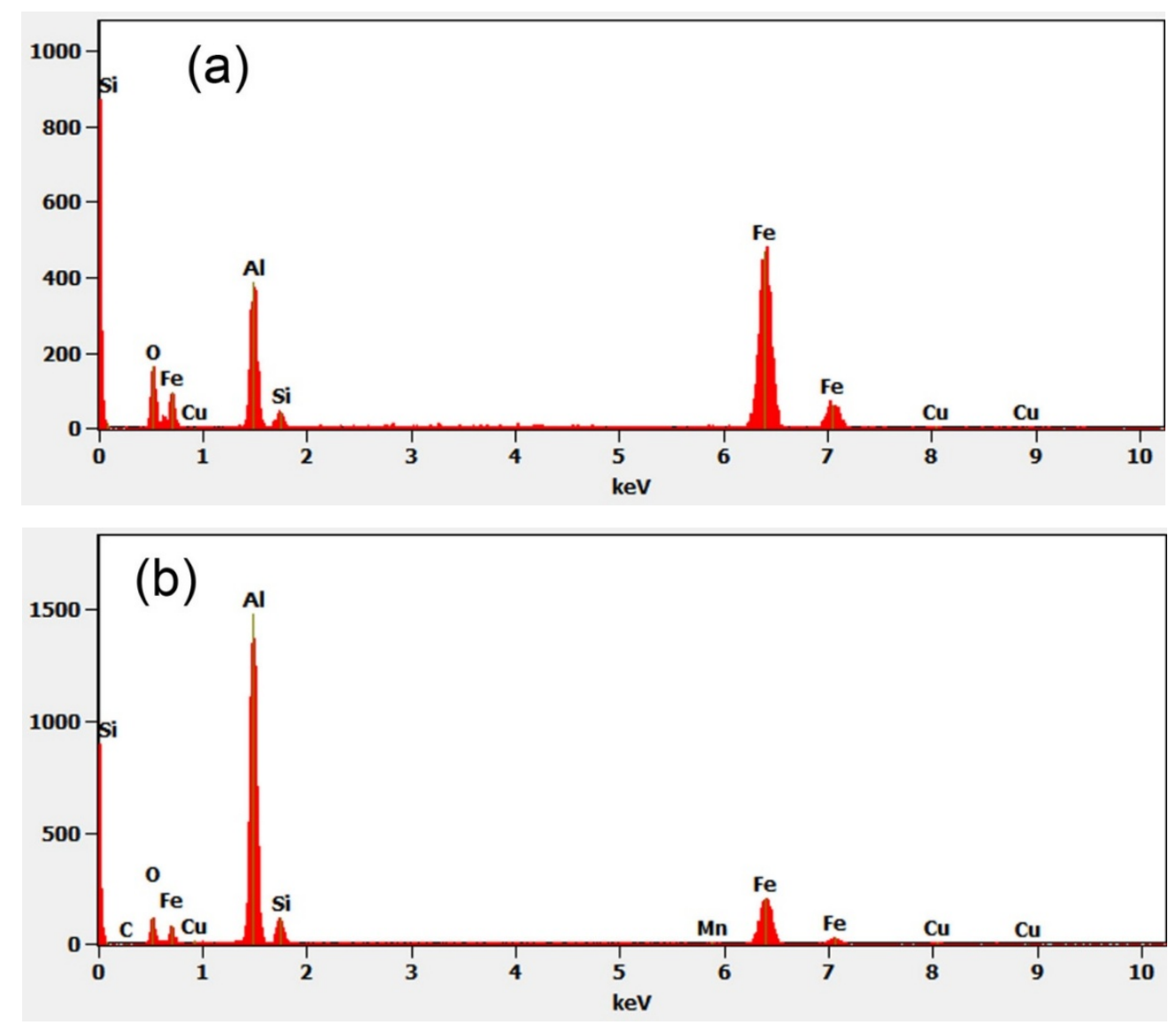

Figure 11. EDS maps of (a) area A and (b) area B.

Because of its fragile nature, the oxide film tended to be broken into fragments at high applied loads during the sliding process. The oxide fragments did not prevent metal-to-metal contact, and thus a high wear volume occurred. Wear behavior of the material was largely dependent on the microstructure of subsurface [29]. As Figure 10a,b shows, delaminating grooves can be distinguished, as well as plastic deformations around the grooves. Such a feature may often be linked with delamination wear, which is the result of cracks beneath the surface that grow and eventually join each other and eventually extend to the pin surface, leading to partial detachment of the wear layers [30,31]. As for the as-cast Al-5Si-1Cu-0.5Mg alloy, at the applied load of $90 \mathrm{~N}$, a combination of delamination and plastic deformation was the dominant wear mechanism, and oxidation wear and abrasion wear also contributed to the wear.

As Figure 10c,d shows, many white powders (Fe-rich mechanical mixture), smooth flat surface (plastic deformation), and slight delamination wear were observed on the wear surface. These features indicated that oxidation wear and abrasion were the dominant wear mchanisms, and that plastic deformation and delamination also contributed to the wear. It can be conclued that $\mathrm{SiCp}$ improves the wear resistance of the matrix. Figure 10e,f show the SEM image of the SiCp/Al-5Si-1Cu-0.5Mg alloy with T6 treatment under a load of $90 \mathrm{~N}$. Besides some tiny scratches, a large area of smooth grooves appear on the wear surface due to the plastic deformation. There are no cracks on the grooves. It indicates that the worn surface could guarantee smooth sliding after plastic deformation. When compared with the $\mathrm{SiCp} / \mathrm{Al}-5 \mathrm{Si}-1 \mathrm{Cu}-0.5 \mathrm{Mg}$ alloy without $\mathrm{T} 6$ treatment, the wear resistance was significantly improved. The wear mechanisms were plastic deformation and abrasion wear.

As shown in Figure 7a,c,e, oxides, plastic deformation and grooves were on the worn surface of alloys at a sliding speed of $0.377 \mathrm{~m} / \mathrm{s}$ and the load of $60 \mathrm{~N}$. These features indicated that oxidation wear and abrasion were the dominant wear mchanisms, and that plastic deformation and delamination also 
contributed to the wear. Figure $7 \mathrm{~b}$ shows that plastic deformation and scratches were formed on the worn surface of the as-cast Al-5Si-1Cu-0.5Mg alloy at a sliding speed of $0.565 \mathrm{~m} / \mathrm{s}$ and the load of $60 \mathrm{~N}$, which could suggest the abrasion wear mechanism. The same wear mechanism was also observed on the worn surfaces of the SiCp/Al-5Si-1Cu-0.5Mg and the SiCp/Al-5Si-1Cu-0.5Mg alloy with T6 treatment at the same sliding conditions. The plastic deformation of the as-cast $\mathrm{Al}-5 \mathrm{Si}-1 \mathrm{Cu}-0.5 \mathrm{Mg}$ alloy was the most seriously and the oxides were the minimum, owing to the high plastic deformation in contact zone and no oxides on the surface. Moreover, the existence of $\mathrm{SiCp}$ particles and $\mathrm{Al}_{2} \mathrm{Cu}$ phase could help to protect the worn surfaces at a sliding of $0.565 \mathrm{~m} / \mathrm{s}$. The dominant wear mechanism of the $\mathrm{SiCp} / \mathrm{Al}-5 \mathrm{Si}-1 \mathrm{Cu}-0.5 \mathrm{Mg}$ alloys with and without $\mathrm{T} 6$ treatment was plastic deformation, oxidation and abrasion wear at sliding speed of $0.565 \mathrm{~m} / \mathrm{s}$ and load of $60 \mathrm{~N}$ (as Figure $7 \mathrm{~d}, \mathrm{f}$ shown).

Figure 12 shows the SEM micrographs of the debris of the SiCp/Al-5Si-1Cu-0.5Mg alloy with T6 treatment and the EDS analysis of point C. As shown in Table 4, $\mathrm{O}$ and Fe content were 10.48 and $33.88 \mathrm{wt} \%$, respectively. The bulk wear debris was generated by the development of plastic strain and crack propagation in the subsurface of the composite. It indicated that delamination wear also occurred during the sliding process except for the wear mechanisms mentioned.
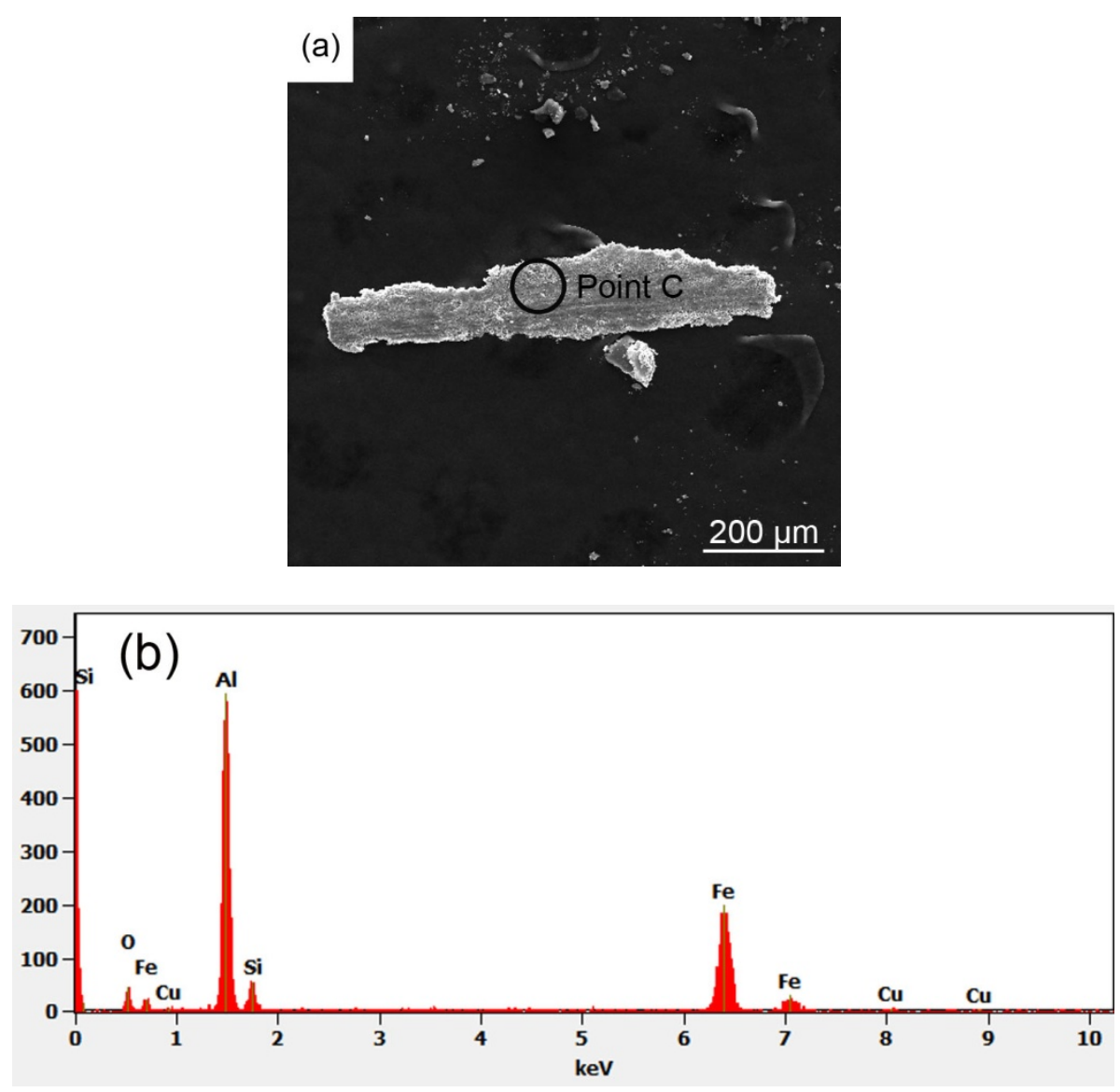

Figure 12. (a) Plate-like debris of the $\mathrm{SiCp} / \mathrm{Al}-5 \mathrm{Si}-1 \mathrm{Cu}-0.5 \mathrm{Mg}$ sample after $\mathrm{T} 6$ heat treatment and (b) EDS result of point $C$.

Table 4. EDS results of area A, area B and point C (wt \%).

\begin{tabular}{cccccccc}
\hline Position & C-K & O-K & Al-K & Si-K & Mn-K & Fe-K & Cu-K \\
\hline Area A & - & 18.77 & 25.50 & 3.19 & - & 51.84 & 0.70 \\
Area B & 0.85 & 17.15 & 51.14 & 8.50 & 0.77 & 19.78 & 1.82 \\
Point C & - & 10.48 & 46.57 & 7.37 & - & 33.88 & 1.69 \\
\hline
\end{tabular}


With the increase of applied loads, a large plastic strain appeared on the wear surface, and the wear rate increased (as Figure 5 shown). Figure 13a-c show the SEM images of the SiCp/Al-5Si-1Cu- $0.5 \mathrm{Mg}$ composite with T6 samples under different loads. Numerous narrow scratches paralleling the sliding direction and few white powders can be distinguished on the wear suface at a load of $15 \mathrm{~N}$ (as shown in Figure 13a). Thus, abrasion wear was the dominant wear mechanism, and oxidation also caused some wear. When compared with Figure 13a, more white powder and deeper and wider scratches were shown in Figure 13b. This indicated that the wear intensity increased. Oxidation wear and abrasion were considered to be the dominant wear mechanisms. Some bulk wear debris were observed and a rugged flat surface appeared indistinctly on the wear surface (as shown in Figure 13c). This indicated that the plastic deformation was present on the wear surface. Meanwhile, the oxidation wear and abrasive wear was still observed. Figure $13 \mathrm{~d}$ shows the SEM images of edging morphology of the as-cast Al-5Si-1Cu-0.5Mg pin sample at $90 \mathrm{~N}$. The edging shape of the pin sample along the sliding direction was irregular due to the pressure of plastic deformation that was caused by the high applied load [32]. In other words, the wear resistance of the Al-5Si-1Cu-0.5Mg alloy was poor.
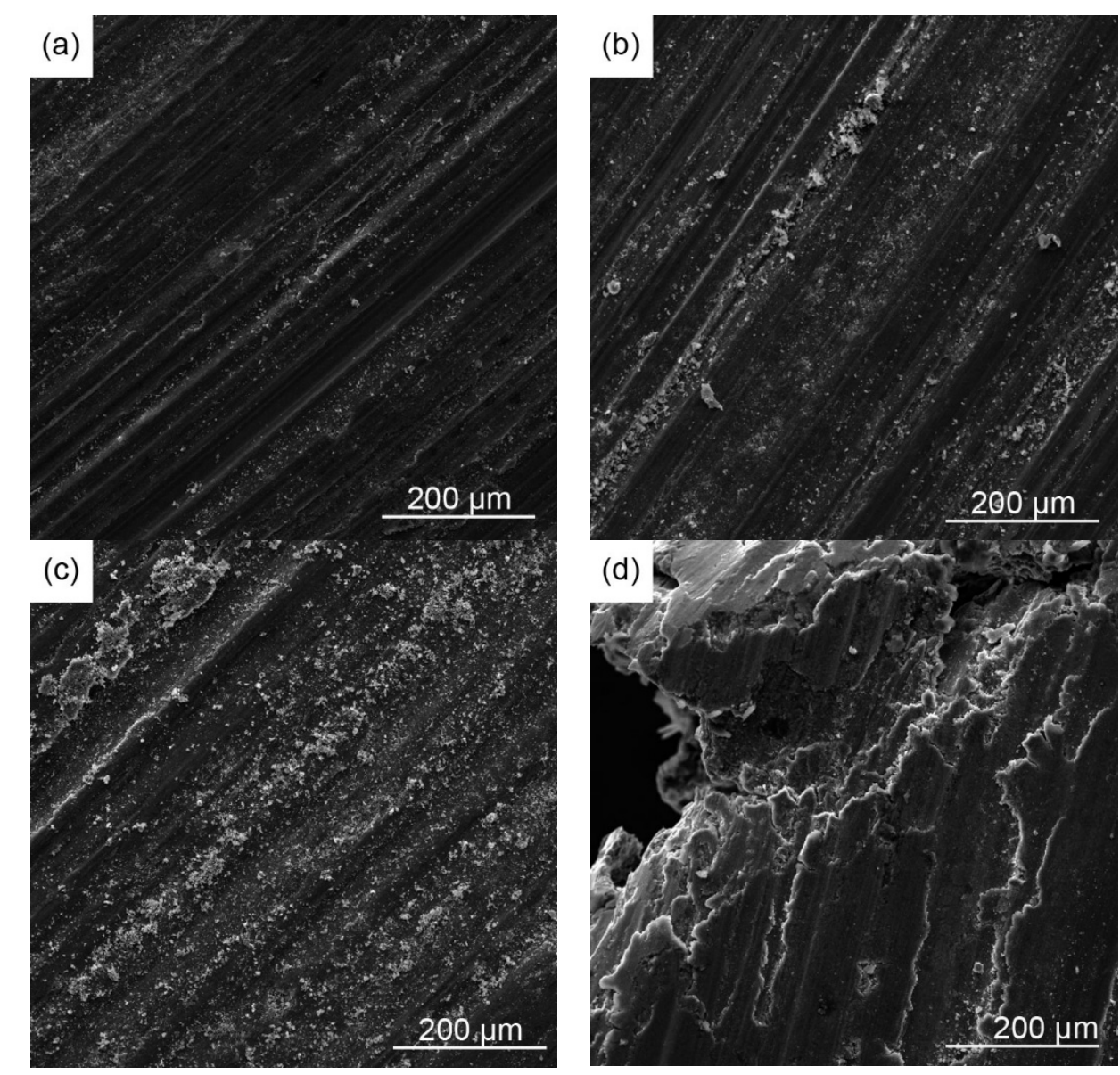

Figure 13. SEM images of SiCp/ Al-5Si-1Cu-0.5Mg composites after T6 heat treatment under normal loads of (a) $15 \mathrm{~N}$, (b) $30 \mathrm{~N}$, (c) $60 \mathrm{~N}$; (d) edging morphology of the as-cast Al-5Si-1Cu-0.5Mg pin sample at $90 \mathrm{~N}$.

\section{Conclusions}

A pin-on-disc dry sliding wear test of three alloys processed by the electromagnetic stirring method was conducted at room temperature. The alloys included as-cast Al-5Si- $1 \mathrm{Cu}-0.5 \mathrm{Mg}$ alloy, as-cast $\mathrm{SiCp} / \mathrm{Al}-5 \mathrm{Si}-1 \mathrm{Cu}-0.5 \mathrm{Mg}$, and $\mathrm{SiCp} / \mathrm{Al}-5 \mathrm{Si}-1 \mathrm{Cu}-0.5 \mathrm{Mg}$ alloy with $\mathrm{T} 6$ heat treatment. The conclusions of this investigation are as follows: 
(1) After T6 heat treatment, the morphology of the eutectic silicon was spheroidal, and some light grey $\gamma$ phases precipitated. The mechnical properties of SiCp/Al-5Si-1Cu-0.5Mg alloy with $\mathrm{T} 6$ treatment performed the best of all. After T6 treatment, the hardness, ultimate strength, and elongation of the alloy were $101.86 \mathrm{HV}, 273.64 \mathrm{MPa}$, and $6.12 \%$, respectively. These values increased by $27 \%$, $42.85 \%$ and $60.63 \%$, respectively, when compared with the ones of as-cast $\mathrm{Al}-5 \mathrm{Si}-1 \mathrm{Cu}-0.5 \mathrm{Mg}$.

(2) As the applied load increasing, the wear rates and friction coefficients of the alloy increased. The SiCp/ Al-5Si-1Cu-0.5Mg alloy with T6 treatment achieved the lowest wear rate and lowest friction coefficient of all the alloys. This indicated that T6 heat treatment benefited for the improvement of the wear properties of the alloy.

(3) As the sliding speed increasing, the wear rates and friction coefficients of the alloy decreased. SiCp particles and $\mathrm{Al}_{2} \mathrm{Cu}$ phase had positive effects on the wear behavior of the alloy. With the sliding speed increase, the amount of delaminating grooves on the worn surface was decreased and the worn surface became smooth. The $\mathrm{SiCp} / \mathrm{Al}-5 \mathrm{Si}-1 \mathrm{Cu}-0.5 \mathrm{Mg}$ alloy with $\mathrm{T} 6$ treaement achieced the lowest wear rate and lowest friction coefficient of all the alloys.

(4) Abrasion and oxidation wear were dominant at low loads $(15,30 \mathrm{~N})$. When the applied load increased to $60 \mathrm{~N}$, plastic deformation was also observed on the wear surface. At a high applied load $(90 \mathrm{~N})$, plastic deformation and delamination were the main mechanisms of wear for the as-cast Al-5Si-1Cu-0.5Mg alloy. With SiCp addition, the degree of delamination was decreased. After T6 heat treatment, the worn surface of $\mathrm{SiCp} / \mathrm{Al}-5 \mathrm{Si}-1 \mathrm{Cu}-0.5 \mathrm{Mg}$ alloy became smooth and flat, and no cracks were observed on the wear surface. As a result, the wear resistance of the $\mathrm{SiCp} / \mathrm{Al}-5 \mathrm{Si}-1 \mathrm{Cu}-0.5 \mathrm{Mg}$ alloy was improved.

Acknowledgments: This work was supported by the national natural science foundation of china (No. 51364035), Loading Program of science and Technology of College of Jiangxi Province (No. KJLD14003).

Author Contributions: Ning $\mathrm{Li}$ and Hong Yan conceived and designed the experiments; Ning $\mathrm{Li}$ and Zhi-Wei Wang performed the experiments; Ning Li, Hong Yan and Zhi-Wei Wang analyzed the data; Ning Li, Hong Yan and Zhi-Wei Wang contributed reagents/materials/analysis tools; Ning Li, Hong Yan and Zhi-Wei Wang wrote the paper.

Conflicts of Interest: The author declares no conflict of interest.

\section{References}

1. Choi, S.W.; Cho, H.S.; Kang, C.S.; Kumai, S. Precipitation dependence of thermal properties for Al-Si-Mg-Cu-(Ti) alloy with various heat treatment. J. Alloys Compd. 2015, 647, 1091-1097. [CrossRef]

2. Rao, Y.S.; Yan, H.; Hu, Z. Modification of eutectic silicon and $\beta$-Al5FeSi phases in as-cast ADC12 alloys by using samarium addition. J. Rare Earth. 2013, 9, 916-922. [CrossRef]

3. Liu, G.; Li, G.D.; Cai, A.H.; Chen, Z.K. The influence of Strontium addition on wear properties of Al-20 wt \% Si alloys under dry reciprocating sliding condition. Mater. Des. 2011, 32, 121-126. [CrossRef]

4. Jian, X.S.; Wang, N.J.; Zhu, D.G. Friction and wear properties of in-situ synthesized $\mathrm{Al}_{2} \mathrm{O}_{3}$ reinforced aluminum composites. Trans. Nonferr. Met. Soc. China 2014, 24, 2352-2358. [CrossRef]

5. Du, X.F.; Gao, T.; Liu, G.L.; Liu, X.F. In situ synthesizing SiC particles and its strengthening effect on an Al-Si-Cu-Ni-Mg piston alloy. J. Alloys Compd. 2017, 695, 1-8. [CrossRef]

6. Rajeev, V.R.; Dwivedi, D.K.; Jain, S.C. Effect of load and reciprocating velocity on the transition from mild to severe wear behavior of Al-Si-SiCp composites in reciprocating conditions. Mater. Des. 2010, 31, 4951-4959. [CrossRef]

7. Khosravi, H.; Akhlaghi, F. Comparison of microstructure and wear resistance of A356-SiCp composites processed via compocasting and vibration cooling slope. Trans. Nonferr. Met. Soc. China 2015, 25, 2490-2498. [CrossRef]

8. Gupta, A.K.; Prasad, B.K.; Pajnoo, R.K.; Das, S. Effects of T6 heat treatment on mechanical, abrasive and erosive-corrosive wear properties of eutectic Al-Si alloy. Trans. Nonferr. Met. Soc. China 2012, 22, 1041-1050. [CrossRef]

9. Singh, J.; Chauhan, A. Overview of wear performance of aluminum matrix composites reinforced with ceramic materials under the influence of controllable variables. Ceram. Int. 2016, 42, 56-81. [CrossRef] 
10. Choi, J.P.; Hur, Y.M.; Nam, T.W.; Yoon, E.P. The effect of frequency of electromagnetic vibration on the micro structure in hypoeutectic Al-Si Alloy. Solid State Phenom. 2006, 116-117, 213-216. [CrossRef]

11. Yu, H.Q.; Zhu, M.Y. Effect of electromagnetic stirring in mold on the macroscopic quality of high carbon steel billet. Acta Metall. Sin. 2009, 22, 461-467. [CrossRef]

12. Zhu, G.L.; Xu, J.; Zhang, Z.F.; Bai, Y.L.; Shi, L.K. Annular electromagnetic stirring-A new method for the production of semi-solid A357 aluminum alloy slurry. Acta Metall. Sin. 2009, 22, 408-414. [CrossRef]

13. Metan, V.; Eigenfeld, K.; Rabiger, D.; Leonhardt, M.; Eckert, S. Grain size control in Al-Si alloys by grain refinement and electronmagnetic stirring. J. Alloys Compd. 2009, 487, 163-172. [CrossRef]

14. Liu, Z.; Mao, W.M.; Liu, X.M. Characterization on morphology evolution of primary phase in semisolid A356 under slightly electromagnetic stirring. Trans. Nonferr. Met. Soc. China 2010, 20, 805-810. [CrossRef]

15. Dwivedi, S.P.; Sharma, S.; Mishra, R.K. Microstructure and mechanical properties of A356/SiC composites fabricated by electromagnetic stir casting. Procedia Mater. Sci. 2014, 6, 1524-1532. [CrossRef]

16. Liu, G.P.; Wang, Q.D.; Liu, T.; Ye, B.; Jiang, H.Y.; Ding, W.J. Effect of T6 heat treatment on microstructure and mechanical property of 6101/A356 bimetal fabricated by squeeze casting. Mater. Sci. Eng. A 2017, 696, 208-215. [CrossRef]

17. Yan, H.; Wan, J.; Nie, Q. Wear Behavior of Extruded Nano-SiCp Reinforced AZ61 Magnesium Matrix Composites. Adv. Mech. Eng. 2015, 5, 489528. [CrossRef]

18. Rohatgi, P.K.; Ray, S.; Asthana, R.; Narendranath, C.S. Interfaces in cast metal-matrix composites. Mater. Sci. Eng. A 1993, 162, 163-174. [CrossRef]

19. Wang, W.; Ajersch, F.; Löfvander, J.P.A. Si phase nucleation on SiC particulate reinforcement in hypereutectic Al-Si alloy matrix. Mater. Sci. Eng. A 1994, 187, 65-75. [CrossRef]

20. Sjölander, E.; Seifeddine, S. The heat treatment of Al-Si-Cu-Mg casting alloys. J. Mater. Process. Technol. 2010, 210, 1249-1259. [CrossRef]

21. Chu, H.S.; Liu, K.S.; Yeh, J.W. Study of $6061-\mathrm{Al}_{2} \mathrm{O}_{3 p}$ composites produced by reciprocasting extrusion. Metall. Mater. Trans. A 2000, 31, 2587-2596. [CrossRef]

22. Archard, J.F. Contact and rubbing of flat surfaces. J. Appl. Phys. 1953, 24, 981-988. [CrossRef]

23. Yan, H.; Wang, Z.W. Effect of heat treatment on wear properties of extruded AZ91 alloy treated with yttrium. J. Rare Earths 2016, 34, 308-314. [CrossRef]

24. Bowden, F.P.; Tabor, D. The Friction and Lubrication of Solids; Clarendon Press: London, UK, 1964; pp. 1-8. ISBN 9780198507772.

25. An, J.; Li, R.G.; Lu, Y.; Chen, C.M.; Xu, Y.; Chen, X.; Wang, L.M. Dry sliding wear behavior of magnesium alloys. Wear 2008, 265, 97-104. [CrossRef]

26. Ramezani, M.; Ripin, Z.M. A friction model for dry contacts during metal-forming process. Int. J. Adv. Manuf. Technol. 2010, 51, 93-102. [CrossRef]

27. Lashgari, H.R.; Sufizadeh, A.R.; Emamy, M. The effect of strontium on the microstructure and wear properties of A356-10\%B4C cast composites. Mater. Des. 2010, 31, 2187-2195. [CrossRef]

28. Dwivedi, D.K.; Arjun, T.S.; Thakur, P.; Vaidya, H.; Singh, K. Sliding wear and friction behaviour of Al-18\% Si-0.5\% Mg alloy. J. Mater. Process. Technol. 2004, 152, 323-328. [CrossRef]

29. Abouei, V.; Shabestari, S.G.; Saghafian, H. Dry sliding wear behaviour of hypereutectic Al-Si piston alloys containing iron-rich intermetallics. Mater. Charact. 2010, 61, 1089-1096. [CrossRef]

30. Suh, N.P. An overview of the delamination theory of wear. Wear 1977, 44, 1-16. [CrossRef]

31. Zhu, J.B.; Yan, H. Fabrication of an A356/fly-ash-mullite interpenetrating composite and its wear properties. Ceram. Int. 2017, 43, 12996-13003. [CrossRef]

32. Asl, K.M.; Masoudi, A.; Khomamizadeh, F. The effect of different rare earth elements content on microstructure, mechanical and wear behavior of Mg-Al-Zn alloy. Mater. Sci. Eng. A 2010, 527, 2027-2035.

(C) 2018 by the authors. Licensee MDPI, Basel, Switzerland. This article is an open access article distributed under the terms and conditions of the Creative Commons Attribution (CC BY) license (http://creativecommons.org/licenses/by/4.0/). 